\title{
Personal characteristics and styles of coping with stress of nursing students of a university in Turkey
}

\author{
Pınar Yeșil, Gürsel Öztunç, Zehra Eskimez \\ Nursing Department, Cukurova University Adana Health School, Adana, Turkey
}

Received: January 7, 2015

Accepted: March 3, 2015

Online Published: March 10, 2015

DOI: $10.5430 /$ jnep.v5n5p73

URL: http://dx.doi.org/10.5430/jnep.v5n5p73

\begin{abstract}
Objective: University studentship and the university life itself have the potential to create worry and stress. Nursing education is a hard and stressful process. The purpose of this study is to identify nursing students' ways of coping with stress.

Methods: The study was designed as a descriptive and cross-sectional. Target population of this study was all the students who were enrolled in a nursing school of a university located in Turkey. The data were collected "Personal Information Form", developed by the researchers in light of the related literature, with a view to identifying socio-demographic features of the participants and "Ways of Coping Questionnaire" with a view to finding out the ways of coping with stress.

Results: The participants of the study were 467 students. An evaluation of the WoCQ sub-scale mean scores of the nursing students in the present study showed that they got $21.15 \pm 3.92$ from the self-confident style, $14.03 \pm 2.87$ from the optimistic style, and $12.04 \pm 2.97$ from the seeking social support. An evaluation of the WoCQ sub-scale mean scores of the nursing students according to grade level shows that first graders got $12.13 \pm 2.19$ from the submissive style $(p=.037)$, who were pleased with the school tended to be more self-confident and who could not communicate with the opposite sex tended to have a more helpless style $(p=.004)$ in coping with stress.

Conclusions: Results of the present study indicate that various factors play a role in nursing students' ways of coping with stress and they seem to cope with stress effectively.
\end{abstract}

Key Words: Stress, Coping, Nursing students

\section{INTRODUCTION}

Stress, defined as one's excessive physical and psychological effort spent due to the no compatible conditions coming from physical or social environment, is a situation that has to be coped with. ${ }^{[1]}$ People encounter many stressors throughout their lives. University studentship and the university life itself have the potential to create worry and stress. Nursing education is a hard and stressful process. ${ }^{[2-4]}$

Clinical education is a critical and complex component of nursing education that is influenced by many variables. ${ }^{[5]}$
Beside the conflicts they experience as university students, nursing department students can encounter various problems arising from school and hospital environments. ${ }^{[3]}$ These problems include overloaded course schedule, practical training in busy and stressful hospital environments, looking after patients, having problems with instructors and hospital personnel, preparing and implementing medication in clinics, and taking responsibility of patients' health and safety. ${ }^{[3,4,6,7]}$ In addition to the tension and stress accompanied by the clinical practices, some other factors that cause stress for nursing students are keeping up with different dormitory and social

\footnotetext{
*Correspondence: Pınar Yeşil; Email: pnar.yesil@gmail.com; Address: Çukurova University, Adana Saglik Yuksekokulu Balcali Kampusu, 01330,
} Adana, Turkey.

Published by Sciedu Press 
environment conditions, maintaining academic standards of the school, and having difficulties such as sexual compatibility and peer pressure. ${ }^{[6,8]}$ Coping with stress is defined as cognitive, behavioral or emotional response given with a view to enduring, reducing or eliminating the tension caused by stressful events or situations. ${ }^{[9]}$

The process of coping is a very complex response that occurs when an individual attempts to remove stress or a perceived threat from the environment. Coping responses can be described as positive or negative and as reactive. ${ }^{[10]}$ Lazarus and Folkman identified two independent types of coping "problem-based and emotion-based".[11,12] Emotion focused coping refers to efforts to regulate an emotional response and ultimately alleviate emotional symptoms of distress, the stabilization of emotional balance. Problem-focused coping, on the other hand, describes actions. ${ }^{[13]}$ Both can be used to effect, but emotion-based coping is more frequently expressed in ineffective ways. ${ }^{[12]}$

The purpose of coping is to reduce the amount of stress which has negative effects on life and productivity. In order for students under pressure to be able to cope with stress, they should have knowledge about factors causing stress, attitudes for coping with stress and using these methods when necessary. ${ }^{[9,14]}$ Therefore, it is important to evaluate the effective coping level of university students both as individuals and as personnel responsible for improving health in relation to stress which can have negative effects on physical and emotional health. ${ }^{[1]}$

Researchers have found that socio-demographic features influenced coping behaviors. ${ }^{[14-17]}$ The purpose of this study is to identify nursing students' ways of coping with stress.

\section{Methods}

Target population of this descriptive and cross-sectional study was all the students who were enrolled in a nursing school of a university located in Adana/Turkey. The participants were 467 students. The purpose was to reach the whole population, thus no sampling was used; the participation ratio was $71 \%$. The data were collected through the 20 -item "Personal Information Form", developed by the researchers in light of the related literature, with a view to identifying socio-demographic features of the participants and "Ways of Coping Questionnaire (WoCQ)" with a view to finding out the ways of coping with stress.

Personal Information Form consists of 20 questions: 11 questions regarding the students' socio-demographic features (age, gender, number of siblings, mother's education level, father's education level, etc.) and 9 questions regarding views about self and status of participating in social and sports activities and being pleased with the profession. ${ }^{[9,16]}$
Short form of Ways of Coping Questionnaire is a 4 point Likert-type scale, originally was developed by Folkman \& Lazarus (1980) and named as "Ways of Coping Questionnaire (WoCQ)". ${ }^{[18]}$ Elimination of the first limited part, adaptation of the scale to Turkish culture were performed, were shortened 30 items and were conducted validity and reliability studies by Şahin \& Durak (1995). ${ }^{[19]}$ WoCQ sub-scales are scored separately and independently from each other. The five sub-scales are "Self-confident Style" with seven items (8-10-14-16-20-23-26), "Optimistic Style" with five items (2-4-6-12-18), "Helpless Style" with eight items (3-7-1119-22-25-27-28), "Seeking Social Support Style" with four items (1-9-29-30), and "Submissive Style" with six items (513-15-17-21-24). ${ }^{[16]}$ Cronbach's alpha reliability scores for WoCQ sub-scales are "0.62-0.80” for Self-confident Style, “0.49-0.68” for Optimistic Style, "0.64-0.73” for Helpless Style, “0.45-0.47” for Seeking Social Support Style, “0.470.72 " for Submissive Style. ${ }^{[16]}$

Respondents are asked to indicate the item that applies them most and choose among the alternatives which are "0\% (does not apply), 30\% (used quite a bit), 70\% (used a great deal), and $100 \%$ (applies or used)". Item number 1 and 9 are scored reversely (from 4 to 1) while the other items are scored between 1 and 4 . Raw scores are obtained by adding the items belonging to each sub scale, and thus each student obtains five different scores for five different sub-scales. ${ }^{[18]}$ The evaluation of the questionnaire shows that coping becomes effective with the increase in the scores belonging to selfconfident, optimistic, and seeking social support styles. On the other hand, an increase in the helpless and submissive styles indicates the use of less effective methods in coping with stress. ${ }^{[20]}$

\subsection{Statistical analysis}

Compatibility of the data was tested; analysis of those which did not display normal distribution was performed using Mann Whitney U or Kruskal Walls tests. The data were displayed using means, standard deviations, numbers, and percentages.

\subsection{Ethical considerations}

Written consent was taken from the institution where the study was conducted. Students were informed about the aims of the study and their verbal consent was obtained prior to the administration of the questionnaire.

\section{RESUlts}

The average age of the participants was $20.30 \pm 1.7$, and $40.3 \%$ of them were first graders. In addition, $69.2 \%$ of the participants were females, and $64 \%$ chose their profession willingly (see Table 1). 
Table 1. Frequency of students' socio-demographical features

\begin{tabular}{|c|c|c|c|}
\hline Variables & & $N$ & $\%$ \\
\hline \multirow{2}{*}{ Gender } & Female & 323 & 69.2 \\
\hline & Male & 144 & 30.8 \\
\hline \multirow{4}{*}{ Grade level } & First grade & 188 & 40.3 \\
\hline & Second grade & 114 & 24.4 \\
\hline & Third grade & 102 & 21.8 \\
\hline & Fourth grade & 63 & 13.5 \\
\hline \multirow{3}{*}{ Place of living } & Village & 75 & 16.0 \\
\hline & Town & 147 & 31.5 \\
\hline & Metropolis & 245 & 52.5 \\
\hline \multirow{5}{*}{ People they live with } & Dormitory & 109 & 23.3 \\
\hline & Family & 241 & 51.6 \\
\hline & Friend(s) & 76 & 16.3 \\
\hline & Alone & 30 & 6.4 \\
\hline & Relative & 11 & 2.4 \\
\hline \multirow{2}{*}{ Mother's profession } & Working & 34 & 7.3 \\
\hline & Not working & 433 & 92.7 \\
\hline \multirow{2}{*}{ Father's profession } & Working & 314 & 67.2 \\
\hline & Retired & 153 & 32.8 \\
\hline \multirow{5}{*}{ Mother's education level } & Literate & 52 & 11.1 \\
\hline & Illiterate & 76 & 16.3 \\
\hline & Primary school & 231 & 49.5 \\
\hline & High school & 98 & 21.0 \\
\hline & College or University & 10 & 2.1 \\
\hline \multirow{5}{*}{ Father's education level } & Literate & 20 & 4.3 \\
\hline & Illiterate & 19 & 4.0 \\
\hline & Primary school & 216 & 46.3 \\
\hline & High school & 164 & 35.1 \\
\hline & College or University & 48 & 10.3 \\
\hline \multirow{2}{*}{ Family type } & Large family & 79 & 16.9 \\
\hline & Nuclear family & 388 & 83.1 \\
\hline \multirow{2}{*}{ Income level } & Income lower than expenses & 141 & 30.2 \\
\hline & Income equal to or more than expenses & 326 & 69.9 \\
\hline \multirow{2}{*}{ Choosing this profession } & Willingly & 299 & 64.0 \\
\hline & Unwillingly & 168 & 36.0 \\
\hline
\end{tabular}

Of all the participants, $52.5 \%$ spent most of their lives in cities, mothers of $92.7 \%$ were housewives, fathers of $67.2 \%$ worked, $46.3 \%$ of the fathers graduated from primary school while $32.8 \%$ of them were retired, and $49.5 \%$ of the mothers graduated from primary school. Besides, $50.3 \%$ of the students were pleased with their school, $62.5 \%$ participated in social activities and $37.5 \%$ engaged in sports activities, $69.4 \%$ could communicate with the opposite sex, and $88 \%$ were pleased with their physical appearance (see Table 2).
An evaluation of the WoCQ sub-scale mean scores of the nursing students in the present study showed that they got $21.15 \pm 3.92$ from the self-confident style, $14.03 \pm 2.87$ from the optimistic style, and $12.04 \pm 2.97$ from the seeking social support (see Table 3).

An evaluation of the WoCQ sub-scale mean scores according to gender demonstrated that female students got higher scores in helpless and submissive styles than male students did. On the other hand, male students got higher scores in 
optimistic and seeking social support styles when compared to females. There was a statistically significant difference between WoCQ sub-scale mean scores according to gender $(p<.05)$ (see Table 4$)$.

Table 2. Frequency of students' some personal features

\begin{tabular}{llll}
\hline Variables & & N & \% \\
\hline Having disagreements with the family & Yes & 91 & 19.5 \\
Being pleased with the school & No & 376 & 80.5 \\
Participating in sports activities & Pleased & 232 & 49.7 \\
& Not pleased & 235 & 50.3 \\
Engaging in social activities & Yes & 175 & 37.5 \\
& No & 292 & 62.5 \\
Communicating with the opposite sex & Yes & 286 & 38.8 \\
& No & 181 & 69.4 \\
Being pleased with the physical appearance & I communicate easily & 324 & 26.6 \\
Smoking & I have difficulty & 124 & 4.1 \\
& I cannot communicate & 19 & 88.0 \\
\hline
\end{tabular}

An evaluation of WoCQ sub-scale mean scores according to parents' education level showed that children of illiterate parents got $21.82 \pm 3.03$ from the self-confident and 14.93 \pm 2.56 from the optimistic styles and children of parents who graduated from primary school got 12.19 \pm 2.12 from the seeking social support style. There was a statistically significant difference between these sub-scales and mothers' education level $(p<.05)$ (see Table 4$)$.

Table 3. Mean scores for students' ways of coping questionnaire

\begin{tabular}{ll}
\hline \multirow{2}{*}{ Variables } & Ways of Coping Questionnaire \\
\cline { 2 - 2 } & $\boldsymbol{X} \pm \boldsymbol{S D}$ \\
\hline Self-confident Style & $21.15 \pm 3.92$ \\
Optimistic Style & $14.03 \pm 2.87$ \\
Helpless Style & $19.03 \pm 4.36$ \\
Seeking Social Support & $12.04 \pm 2.97$ \\
Submissive Style & $11.92 \pm 2.27$ \\
\hline
\end{tabular}

An evaluation of the WoCQ sub-scale mean scores of the nursing students according to grade level shows that first graders got $12.13 \pm 2.19$ and fourth graders got $11.17 \pm$ 2.27 from the submissive style in coping with stress; there was a statistically significant difference between the submissive style scores according to the grade levels of students ( $p$ $<$.05) (see Table 4).

Students whose fathers received college or university educa- tion were found to get $12.69 \pm 2.07$ from the seeking social support style; and there was a significant difference between these sub-scales and fathers' education level $(p<.05)$ (see Table 4).

Those who chose their profession willingly were found to adopt a more self-confident and optimistic style in coping with stress, and those who did not choose their profession willingly were found to have a hopeless style. Mean scores they got from these sub-scales differed significantly according to choosing profession willingly or not $(p<.05)$ (see Table 4).

An evaluation of the relationship between students' income and WoCQ sub-scale mean scores displayed that students whose income was lower than their expenses had a more helpless style in coping with stress. There was a statistically significant difference between the mean scores they obtained from the helpless style sub-scale and income level $(p<.05)$ (see Table 4).

Those who were pleased with the school tended to be more self-confident in coping with stress; and the difference between being pleased with the school and the scores they obtained from the self-confidence sub-scale was found to be statistically significant $(p<.05)$ (see Table 5).

An evaluation of the WoCQ sub-scale mean scores and engaging in social or sports activities showed that those who participate in social activities were more self-confident in 
coping with stress than those who did not. Those who did not participate in social activities tended to have a more helpless style. The difference between engaging in social activities and the mean scores the participants got from the scale was found to be statistically significant $(p<.05)$. In a similar vein, results showed that those who engaged in sports activ- ities were more optimistic in coping with stress than those who did not. Those who did not engage in sports tended to have a more helpless style. The difference between engaging in social activities and the mean scores the participants got from the scale was found to be statistically significant $(p<$ .05) (see Table 5).

Table 4. Contingency table for students' socio-demographic features and their coping styles

\begin{tabular}{|c|c|c|c|c|c|c|c|}
\hline \multirow[t]{2}{*}{ Variables } & & \multirow[t]{2}{*}{$N$} & $\begin{array}{l}\text { Self-confident } \\
\text { style }\end{array}$ & $\begin{array}{l}\text { Optimistic } \\
\text { style }\end{array}$ & $\begin{array}{l}\text { Helpless } \\
\text { style }\end{array}$ & $\begin{array}{l}\text { Seeking social } \\
\text { support }\end{array}$ & $\begin{array}{l}\text { Submissive } \\
\text { style }\end{array}$ \\
\hline & & & $X \pm S D$ & $X \pm S D$ & $X \pm S D$ & $X \pm S D$ & $X \pm S D$ \\
\hline \multirow{2}{*}{ Gender } & Female & 323 & $21.09 \pm 3.97$ & $13.82 \pm 3.03$ & $19.35 \pm 4.39$ & $11.79 \pm 2.83$ & $12.07 \pm 2.32$ \\
\hline & Male & 144 & $21.28 \pm 3.83$ & $14.49 \pm 2.39$ & $18.31 \pm 4.19$ & $12.60 \pm 3.19$ & $11.59 \pm 2.13$ \\
\hline \multirow[t]{2}{*}{$p$} & & & .627 & .020 & .018 & .006 & .035 \\
\hline & First grade & 188 & $20.90 \pm 4.02$ & $13.96 \pm 3.02$ & $18.99 \pm 4.38$ & $11.95 \pm 2.99$ & $12.13 \pm 2.19$ \\
\hline \multirow{3}{*}{$\begin{array}{l}\text { Grade } \\
\text { level }\end{array}$} & Second grade & 114 & $21.89 \pm 3.68$ & $13.96 \pm 2.79$ & $19.34 \pm 4.6$ & $11.91 \pm 3.00$ & $11.96 \pm 2.16$ \\
\hline & Third grade & 102 & $21.15 \pm 3.74$ & $13.96 \pm 2.81$ & $19.19 \pm 4.18$ & $11.85 \pm 2.88$ & $11.96 \pm 2.50$ \\
\hline & Fourth grade & 63 & $20.52 \pm 4.23$ & $14.44 \pm 2.66$ & $18.32 \pm 4.07$ & $12.86 \pm 2.93$ & $11.17 \pm 2.27$ \\
\hline \multirow[t]{2}{*}{$p$} & & & .095 & .671 & .492 & .135 & .037 \\
\hline & Literate & 52 & $20.25 \pm 3.94$ & $14.06 \pm 2.62$ & $18.06 \pm 3.34$ & $12.69 \pm 3.15$ & $11.88 \pm 2.25$ \\
\hline \multirow{4}{*}{$\begin{array}{l}\text { Mother's } \\
\text { education } \\
\text { level }\end{array}$} & Illiterate & 76 & $21.82 \pm 3.03$ & $14.93 \pm 2.56$ & $18.97 \pm 3.69$ & $12.05 \pm 3.01$ & $11.28 \pm 2.55$ \\
\hline & Primary school & 231 & $21.48 \pm 3.99$ & $13.95 \pm 2.93$ & $19.19 \pm 4.65$ & $11.71 \pm 2.87$ & $12.19 \pm 2.12$ \\
\hline & Secondary-high school & 98 & $20.39 \pm 4.13$ & $13.55 \pm 2.88$ & $19.31 \pm 4.61$ & $12.47 \pm 2.91$ & $11.84 \pm 2.27$ \\
\hline & College or University & 10 & $20.40 \pm 4.95$ & $13.30 \pm 3.68$ & $17.90 \pm 4.15$ & $11.90 \pm 4.01$ & $11.70 \pm 3.06$ \\
\hline \multirow[t]{2}{*}{$p$} & & & .030 & .025 & .408 & .118 & .047 \\
\hline & Literate & 20 & $19.60 \pm 3.98$ & $14.55 \pm 2.16$ & $19.15 \pm 3.25$ & $12.65 \pm 2.42$ & $11.05 \pm 8.34$ \\
\hline \multirow{4}{*}{$\begin{array}{l}\text { Father's } \\
\text { education } \\
\text { level }\end{array}$} & Illiterate & 18 & $21.06 \pm 3.45$ & $14.56 \pm 2.59$ & $18.17 \pm 4.05$ & $11.83 \pm 3.85$ & $11.17 \pm 2.09$ \\
\hline & Primary school & 216 & $21.50 \pm 3.86$ & $14.06 \pm 2.83$ & $19.11 \pm 4.26$ & $11.72 \pm 2.79$ & $11.78 \pm 2.29$ \\
\hline & Secondary-High school & 164 & $20.97 \pm 3.8$ & $14.07 \pm 2.88$ & $18.89 \pm 4.72$ & $12.30 \pm 2.93$ & $12.07 \pm 2.26$ \\
\hline & College or University & 48 & $21.13 \pm 4.16$ & $13.44 \pm 3.18$ & $19.38 \pm 4.12$ & $12.48 \pm 3.35$ & $12.69 \pm 2.07$ \\
\hline \multicolumn{3}{|l|}{$p$} & .262 & .495 & .870 & .218 & .017 \\
\hline \multirow{3}{*}{$\begin{array}{l}\text { Choosing } \\
\text { the } \\
\text { profession } \\
p\end{array}$} & Willingly & 299 & $21.72 \pm 3.79$ & $14.43 \pm 2.86$ & $18.69 \pm 4.33$ & $11.95 \pm 3.00$ & $12.01 \pm 2.38$ \\
\hline & Unwillingly & 168 & $20.12 \pm 3.95$ & $13.30 \pm 2.74$ & $19.62 \pm 4.35$ & $12.20 \pm 2.92$ & $11.77 \pm 2.08$ \\
\hline & & & $<.001$ & $<.001$ & .026 & .397 & .289 \\
\hline \multirow{3}{*}{$\begin{array}{l}\text { Income } \\
\text { level }\end{array}$} & Income lower than expenses & 141 & $21.26 \pm 3.92$ & $14.06 \pm 2.99$ & $19.87 \pm 4.57$ & $11.84 \pm 3.10$ & $11.91 \pm 2.40$ \\
\hline & Income equal to expenses & 287 & $21.14 \pm 3.83$ & $14.06 \pm 2.78$ & $18.78 \pm 4.10$ & $12.23 \pm 2.88$ & $11.90 \pm 2.29$ \\
\hline & Income more than expenses & 39 & $20.74 \pm 4.64$ & $13.67 \pm 3.08$ & $17.85 \pm 4.94$ & $11.36 \pm 3.07$ & $12.18 \pm 1.65$ \\
\hline \multicolumn{3}{|l|}{$p$} & .766 & .717 & .011 & .141 & .763 \\
\hline
\end{tabular}

Students' communicating with the opposite sex and being pleased with their physical appearance were also evaluated in terms of their WoCQ sub-scale mean scores. It was found that those who could not communicate with the opposite sex tended to have a more helpless style. The difference between the scores obtained from helpless style sub-scale mean scores and the state of communicating with the opposite sex was found to be significant $(p<.05)$ (see Table 5).

Those who were pleased with their physical appearance were found to be more optimistic; and those who were not pleased were found to have a more helpless style. The mean scores they obtained were found to be statistically different according to their being pleased with their physical appearance or not $(p<.05)$ (see Table 5). 
Table 5. Contingency table for students' personal features and their coping styles

\begin{tabular}{|c|c|c|c|c|c|c|c|}
\hline Variables & & $N$ & $\begin{array}{l}\text { Self-confident } \\
\text { style }\end{array}$ & $\begin{array}{l}\text { Optimistic } \\
\text { style }\end{array}$ & $\begin{array}{l}\text { Helpless } \\
\text { style }\end{array}$ & $\begin{array}{l}\text { Seeking social } \\
\text { support }\end{array}$ & $\begin{array}{l}\text { Submissive } \\
\text { style }\end{array}$ \\
\hline \multirow{2}{*}{$\begin{array}{l}\text { Being pleased with the } \\
\text { school }\end{array}$} & Pleased & 232 & $21.58 \pm 3.76$ & $14.24 \pm 2.75$ & $18.89 \pm 4.35$ & $11.95 \pm 3.01$ & $12.05 \pm 2.29$ \\
\hline & Not pleased & 235 & $20.71 \pm 4.04$ & $13.81 \pm 2.97$ & $19.16 \pm 4.37$ & $12.13 \pm 2.94$ & $11.80 \pm 2.25$ \\
\hline$p$ & & & .017 & .106 & .505 & .525 & .224 \\
\hline \multirow{2}{*}{$\begin{array}{l}\text { Engaging in social } \\
\text { activities }\end{array}$} & Yes & 286 & $21.45 \pm 3.92$ & $14.19 \pm 2.80$ & $18.56 \pm 4.28$ & $11.95 \pm 3.07$ & $12.01 \pm 2.26$ \\
\hline & No & 181 & $20.66 \pm 3.89$ & $13.77 \pm 2.95$ & $19.77 \pm 4.38$ & $12.19 \pm 2.81$ & $11.78 \pm 2.30$ \\
\hline$p$ & & & .131 & .003 & .395 & .277 & .032 \\
\hline \multirow{2}{*}{$\begin{array}{l}\text { Participating in sports } \\
\text { activities }\end{array}$} & Yes & 175 & $21.56 \pm 3.88$ & $14.45 \pm 2.56$ & $17.95 \pm 4.02$ & $12.11 \pm 3.26$ & $11.90 \pm 2.35$ \\
\hline & No & 292 & $20.90 \pm 3.93$ & $13.77 \pm 3.01$ & $19.67 \pm 4.43$ & $12.00 \pm 2.79$ & $11.94 \pm 2.23$ \\
\hline$p$ & & & .077 & .014 & $<.001$ & .679 & .850 \\
\hline \multirow{3}{*}{$\begin{array}{l}\text { Communicating with the } \\
\text { opposite sex }\end{array}$} & I communicate easily & 324 & $21.39 \pm 4.00$ & $14.13 \pm 2.94$ & $18.59 \pm 4.33$ & $11.83 \pm 3.10$ & $12.04 \pm 2.22$ \\
\hline & I have difficulty & 124 & $20.52 \pm 3.77$ & $13.73 \pm 2.82$ & $19.99 \pm 4.43$ & $12.47 \pm 2.58$ & $11.70 \pm 2.38$ \\
\hline & I cannot communicate & 19 & $21.00 \pm 3.11$ & $14.26 \pm 1.73$ & $20.26 \pm 3.18$ & $12.79 \pm 2.80$ & $11.37 \pm 2.38$ \\
\hline$p$ & & & .110 & .390 & .004 & .069 & .206 \\
\hline \multirow{2}{*}{$\begin{array}{l}\text { Being pleased with the } \\
\text { physical appearance }\end{array}$} & Pleased & 411 & $21.27 \pm 3.95$ & $14.15 \pm 2.79$ & $18.78 \pm 4.26$ & $12.01 \pm 2.99$ & $11.89 \pm 2.28$ \\
\hline & Not pleased & 56 & $20.23 \pm 3.59$ & $13.12 \pm 3.28$ & $20.88 \pm 4.66$ & $12.27 \pm 2.82$ & $12.14 \pm 2.26$ \\
\hline$p$ & & & .063 & .012 & .001 & .543 & .441 \\
\hline
\end{tabular}

\section{Discussion}

Education processes of nursing students may cause a lot of stress resulting from such reasons as expectations about high academic success, lack of clinical practice, and new roles and responsibilities. ${ }^{[21]}$ Coping behaviors play an important role in the adjustment process. ${ }^{[4]}$

An evaluation of the WoCQ sub-scale mean scores showed that the students got $21.15 \pm 3.92$ from the self-confident style, $14.03 \pm 2.87$ from the optimistic style, and $12.04 \pm$ 2.97 from seeking social support. In their study conducted with nursing students, Güler \& Ç1nar ${ }^{[9]}$ found that students got $11.42 \pm 2.82$ from the self-confident style, $11.42 \pm 2.82$ from the optimistic style, and $6.44 \pm 1.62$ from seeking social support. Temel et al. ${ }^{[11]}$ in their study conducted with Health High School students in order to identify their coping with stress, found self-confident style $12.44 \pm 4.00$, optimistic style $7.73 \pm 3.05$, and seeking social support 6.42 \pm 1.91 . The related literature defines coping with stress in two different ways as problem-focused (active) and emotionfocused (inactive) coping. ${ }^{[2,9,11,12]}$ Emotion-focused coping is reported to be a less effective method when compared to problem-focused coping. ${ }^{[11,12]}$ Besides, it is reported that the evaluation of the WoCQ shows that coping becomes effective with the increase in the scores belonging to self-confident, optimistic and seeking social support styles. ${ }^{[20]}$ The participants of the present study seem to cope with stress effectively. Although the heavy stress throughout the nursing education process frequently bores nursing students, it may also help them use the present coping strategies more effectively, seek helping sources, and find new coping styles.

Ways of Coping Questionnaire sub-scale mean scores show that females have got higher scores in the helpless and submissive styles when compared to males; and males' mean scores obtained from optimistic and seeking social support styles are significantly higher than those of females. The difference is statistically significant. In their study conducted with nursing students, Sawatzky et al. ${ }^{[22]}$ found females' self-efficacy scores in coping with stress to be lower than those of males. Parallel to the findings of the present study, in their study conducted with medicine faculty and health college students, Kaya et al. ${ }^{[23]}$ found that males in both departments used a more active style in coping with stress than girls did. Male students in the present study seem to cope with stress more effectively when compared to female students; males also seem to be in a more advantageous position in coping with stress. In this regard, roles and responsibilities expected from males and females in Turkish society might create differences in their coping styles.

An evaluation of the WoCQ sub-scale mean scores of the nursing students according to grade level shows that first graders got $12.13 \pm 2.19$ and fourth graders got $11.17 \pm 2.27$ from the submissive style in coping with stress; there was a statistically significant difference between the submissive style scores according to the grade levels of students. The 
statistically significant difference can be originating from the large amount of first graders in the sample. In their study conducted with nursing students, Güler \& Çınar ${ }^{[9]}$ found a significant difference between the grade level and scores belonging to submissive and seeking social support styles. Although the present study does not indicate similar results, Temel et al. ${ }^{[16]}$ found that nursing students' self-confident style scores differed according to their grade level. Besides, Amr et al. ${ }^{[24]}$ found that $45 \%$ the first graders and $34.8 \%$ of the last graders in nursing departments experienced heavy stress, but the results did not display statistically significant differences. In their first year of nursing education, students might have a more submissive style due to adaptation difficulties resulting from such factors as adapting dormitory and social environment conditions, maintaining the high academic standards of the school, practical training in the busy and stressful hospital environments, taking responsibility of ill people, and experiencing communication problems with instructors and hospital personnel.

The relationship between WoCQ sub-scale mean scores and education level of parents shows that students with illiterate parents had more self-confident and optimistic styles; and the students whose parents graduated from primary school had a more seeking social support style. The difference was statistically significant. Considering the importance and role of mothers in preparing their children for life through child education, self-confidence and optimistic style are expected to increase with the increase in mothers' education level. It was found that students whose parents were illiterate or graduated from primary school were able to cope with stress effectively. However, results obtained from the present study demonstrate the opposite. In their study which aimed to identify the stress level of nursing students, Amr et al. ${ }^{[24]}$ found that $63.3 \%$ of the students whose parents' education level is lower than secondary school had low level of stress. It was also found that students whose father graduated from university tended to seek social support; there was a statistically significant relationship between these areas and father's education level. Amr et al. ${ }^{[24]}$ found that $67.8 \%$ of the students whose fathers' education level was higher than secondary school had low level of stress.

Those choosing the profession willingly are more selfconfident and optimistic in coping with stress; and those not choosing the profession willingly tend to have a more helpless style. Mean scores received from these sub-scales are statistically significant according to choosing the profession willingly or not. Choice of profession is an important decision that can have good or bad effects in one's future life. ${ }^{[25]}$ Factors such as interest, willingness, and ability should be prerequisites in choosing the nursing profession. ${ }^{[26]}$ Know-

Published by Sciedu Press ing about the working conditions of a profession and choosing it willingly are important factors in performing it well and reaching job satisfaction. Foundations of adopting a profession and performing it well, namely professional consciousness is built during studentship years and continues throughout the professional life. ${ }^{[27]}$ Therefore, those who choose the profession willingly seem to adopt a more problem-focused style about the problems they encounter.

The participants who are pleased with their school adopt a more self-confident style in coping with stress, and there is a statistically significant difference between the mean scores of the self-confidence sub-scale and being pleased with the school. In line with this finding, Temel et al. ${ }^{[16]}$ and Tatar \& Özgür ${ }^{[28]}$ found that students who were pleased with their school had higher mean scores in self-confident and optimistic styles.

Another study indicates that improving learning-teaching environments enhances coping with stress by increasing the satisfaction level. ${ }^{[29]}$ Nursing education requires providing care to healthy and ill people in line with their needs and thus it is a stressful process, which affects the status of being pleased with the school negatively and increases the present anxiety. ${ }^{[16]}$

The present study indicates that those who participate in social activities are more self-confident; and those who do not engage in social activities tend to be more helpless. Mean scores differ significantly according to engaging in a social activity. In line with this finding, a number of studies show that nursing students who have social support system and have good communication skills in their relationships with instructors, friends and patients can cope with stress better. $^{[30,31]}$

Those who engage in sports are more optimistic in coping with stress, and those who do not engage in sports tend to have a more helpless style. Mean scores differ significantly according to engaging in a sports activities. In an experimental study, Hsieh ${ }^{[21]}$ found that nursing students who received 16-week regular physical exercises program decreased their stress scores dramatically and reinforced their coping styles.

\section{CONCLUSION AND IMPlications}

Results of the present study indicate that various factors play a role in nursing students' ways of coping with stress and they seem to cope with stress effectively.

It is further required that coping ways of nursing students should be evaluated at certain intervals; nursing students should be supported so that they can develop positive coping styles; students, especially girls, should be provided with this 
support starting from the first grade; orientation programs for first-year students should include stress management as a topic of discussion, workshops on stress and strategies to cope with stress; social activities should be increased; and the courses which will strengthen their levels of coping with stress should be included in the education program.

\section{Recommendations and limitations}

In line with the findings of the present study, it is recommended that the study should be replicated in larger groups. Results of the present study which was conducted in only one nursing school in Adana/Turkey cannot be generalized to all nursing students.

\section{ACKNOWLEDGEMENTS}

We would like to thank to Çukurova University Adana Health School Nursing Department students M. Emre Keleş, M. Deniz Taşçı and İrfan Bertizlioğlu their help in collecting data and Prof. Dr. Gülşah Şeydaoğlu, an instructor in Çukurova University Medicine Faculty Biostatistics Department, for her help in performing statistical analyses.

\section{CONFLICTS OF INTEREST Disclosure}

The authors declared no conflicts of interest with respect to the authorship and/or publication of this article. This study was not funded by any organization.

\section{REFERENCES}

[1] Gökler R, Işıtan İ. Disease of the modern age: stress and its effects. Journal of History Culture and Art Research. 2012; 1(3): 154-168.

[2] Sawatzky JA. Understanding nursing students' stress: a proposed framework. Nurse Educ Today. 1998; 18(2): 108-15. http://dx.d oi.org/10.1016/S0260-6917 (98) 80014-2

[3] Dinçer F, Öztunç G. Nursing and midwifery department students' self-respect and assertiveness levels. Faculty of Health Sciences Nursing Journal. 2009; 16: 22-33.

[4] Reeve KL, Shumaker CJ, Yearwood EL, et al. Perceived stress and social support in undergraduate nursing students' educational experiences. Nurse Educ Today. 2013; 33(4): 419-24. PMid:23246284 http://dx.doi.org/10.1016/j.nedt. 2012.11.009

[5] Changiz T, Malekpour A, Boroujeni AZ. Stressors in clinical nursing education in Iran: A systematic review. Iran J Nurs Midwifery Res. 2012; 17(6): 399-407. PMid:23922579

[6] Öztürk C, Aktaş B. An investigation of nursing students' general health status and some affecting factors. The Journal of Ataturk University School of Nursing. 2007; 10(2): 58-65.

[7] Yamashita K, Saito M, Takao T. Stress and coping styles in Japanese nursing students. Int J Nurs Pract. 2012; 18(5): 489 96. PMid:23009378 http://dx.doi.org/10.1111/j.1440-1 72X.2012.02056.x

[8] Koç M, Avşaroğlu S, Sezer A. The relationship between university students' academic success and problem fields. Journal of Selcuk University Institute of Social Sciences. 2004; 11: 483-498.

[9] Güler Ö, Çınar S. Identification of nursing students' perceived stressors and the coping styles they use. Maltepe Üniversity Journal of Nursing Science and Art. 2010; Special Number of the Symposium: 253-261.

[10] Seyedfatemi N, Tafreshi M, Hagani H. Experienced stressors and coping strategies among Iranian nursing students. BMC Nursing. 2007; 6: 1-11. PMid:17999772 http://dx.doi.org/10.1186/1 472-6955-6-11

[11] Lazarus RS. Emotional intelligence: Its relationship to stress, coping, well-being and professional performance in nursing students. J Pers. 2006; 74(1): 9-46. PMid:16451225 http://dx.doi .org/10.11 $11 / j .1467-6494.2005 .00368 \cdot x$

[12] Gibbons C, Dempster M, Moutray M. Stress, coping and satisfaction in nursing students. J Adv Nurs. 2011; 67(3): 621-
32. PMid:21077931 http://dx.doi.org/10.1111/j.1365-2 $648.2010 .05495 . \mathrm{x}$

[13] Baloğlu N. The relationship between prospective teachers' strategies for coping with stress and their perceptions of student control. Social Behavior and Personality. 2008; 36(7): 903-910. http: //dx.doi.org/10.2224/sbp.2008.36.7.903

[14] Kara D, Koç H. Identification of instructors' coping style behaviours according to some variables. Journal of Business Research. 2009; 1(2): $35-50$

[15] Kariv D, Heiman T. Task-oriented versus emotion-oriented coping strategies: the case of college students. College Student Journal. 2005; 39(1): 72-84.

[16] Temel E, Bahar A, Çuhadar D. Identification of nursing students' coping styles and depression levels. Journal of Health Services Firat. 2007; 2(5): 107-118.

[17] Kaya M, Genç M, Kaya B, et al. Medicine faculty and health high school students' depressive symptoms prevalence, coping styles, and the affecting factors. Turkish Journal of Psychiatry. 2007; 18(2): 37-146.

[18] Folkman S, Lazarus RS. An analysis of coping in a middle-aged community sample. J Health Soc Behav. 1980; 21(3): 219-39. PMid:7410799 http://dx.doi.org/10.2307/2136617

[19] Şahin NH, Durak A. Ways of coping questionnaire: adaptation for Turkish university students. Turkish Journal of Psychology. 1995; 10(34): 56-73.

[20] Kanbay Y, Üstün B. An investigation of nurses' stressors in work life in kars and Artvin and the coping styles they use. Dokuz Eylul University School of Nursing Electronic Journal. 2009; 2(4): 155-161.

[21] Hsieh PL. A school-based health promotion program for stressed nursing students in Taiwan. J Nurs Res. 2011; 19(3): 2307. PMid:21857330 http://dx.doi.org/10.1097/JNR. 0b013e3 18228d010

[22] Sawatzky RG, Ratner PA, Richardson CG, et al. Stress and depression in students: the mediating role of stress management selfefficacy. Nurs Res. 2012; 61(1): 13-21. PMid:22166906 http: //dx.doi.org/10.1097/NNR.0b013e31823b1440

[23] Kaya M, Genç M, Kaya B, et al. Medicine faculty and health high school students' depressive symptoms prevalence, coping styles, and the affecting factors. Turkish Journal of Psychiatry. 2007; 18(2): $37-146$. 
[24] Amr A, El-Gilany AH, El-Moafee H, et al. Stress among Mansoura (Egypt) baccalaureate nursing students. Pan Afr Med J. 2011; 8: 6. http://dx.doi.org/10.4314/pamj .v8i1.71083

[25] Çam O, Khorshid L, Altuğ ÖS. An investigation of level of selfrespect in a nursing high school. Journal of Nursing Research and Development. 2000; 13(1): 33-40.

[26] Şirin A, Öztürk R, Bezci G, et al. Nursing students' choice of profession and views regarding practices. Dirim Medical Journal. 2008; 83: 69-75.

[27] Beydağ KD, Gündüz A, Özer FG. Views of health high school students regarding their education and profession, and expectations from their profession. Pamukkale Journal of Medicine. 2008; 1(3): 137-142.
[28] Tatar Ç, Özgür G. Nurses' ways of coping and the relationship with depression. Journal of Ege University School of Nursing. 2008; 24(1): 67-82.

[29] Decker J, Shellenbarger T. Strategies for nursing faculty to promote a healthy work environment for nursing students. Teaching and Learning in Nursing. 2012; 7: 56-61. http://dx.doi.org/10.1016/j .teln.2010.12.001

[30] Luo Y, Wang H. Correlation research on psychological health impact on nursing students against stress, coping way and social support. Nurse Educ Today. 2009; 29(1): 5-8. PMid:18692281 http://dx.doi.org/10.1016/j.nedt.2008.05.019

[31] Chan CK, So WK, Fong DY. Hong Kong baccalaureate nursing students' stress and their coping strategies in clinical practice. J Prof Nurs. 2009; 25(5): 307-13. PMid:19751936 http://dx.doi.org /10.1016/j.profnurs. 2009.01.018 